\title{
Facies analysis and sequence stratigraphy of the Asmari Formation in the northern area of Dezful Embayment, south-west Iran
}

\section{Fateme ZABIHI ZOERAM ${ }^{1, *}$, Mohammad VAHIDINIA ${ }^{1}$, Asadollah MAHBOUBI $^{1}$ \& Hassan AMIRI BAKHTIAR ${ }^{2}$}

${ }^{1}$ Department of Geology, Faculty of Sciences, Ferdowsi University of Mashhad, Mashhad, Iran

${ }^{2}$ National Iranian South Oil Company (NISOC), Iran

Received January 2013; accepted July 2013

Available online August 15, 2013

DOI: http://dx.doi.org/10.5038/1937-8602.58.1.4

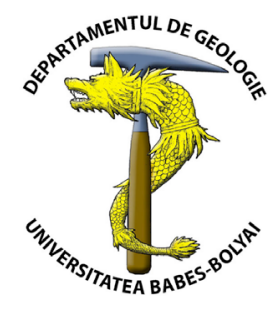

\begin{abstract}
This paper deals with the sequence stratigraphy of the Oligocene (Rupelian-Chattian)-Early Miocene (Burdigalian) Asmari Formation based on microfacies analysis of the sediments in the Ghale Nar Oilfield, central area of Zagros fold-thrust belt. Fourteen facies types typical for upward shallowing trend from open marine (MF 1-3), to shoal (MF 4-5), semi-restricted and restricted lagoon (MF 6-12), and finally to near-shore lagoon (MF 13-14) depositional environments were identified. Based on the environmental interpretations, we reconstructed a homoclinal ramp mainly represented by its inner and middle sectors. Facies types MF 4-14 are characterized by the occurrence of large and small porcelaneous benthic foraminifera representing a shallow-water setting of an inner ramp influenced by wave- and tide-related processes. MF1 (Pabdeh Formation), and 2-3 with planktonic, large and small hyaline benthic foraminifera represent between fair weather wave base (FWWB) and storm wave base (SWB). Four third-order depositional sequences were recognized. In order to better correlate the identified sequences with those pre-defined of the Asmari Formation in the Dezful Embayment and the Izeh zone that are chronologically well-known, we use their number instead of their name. Sequence 2 mainly consists of an open marine environment in the base, followed by semi-restricted to restricted lagoonal facies. Sequences 36 are characterized by semi-restricted to restricted lagoonal facies. Moreover, the regional relative sea-level change curves correlate well with the global sea-level change curves.
\end{abstract}

Keywords: Asmari Formation, Oligocene-Miocene, benthic foraminifera, sequence stratigraphy, carbonate ramp

\section{INTRODUCTION}

Allen and Talebian (2011) discussed the nature of the Dezful Embayment making use of fault patterns and isopach maps. They concluded that this area has been a depocentre since roughly 35 $\mathrm{Ma}$, the time of an initial collision between Arabia and Eurasia. According to these authors, the Dezful Embayment is a trapezoidal area within the Zagros Simply Folded Belt (Fig. 1), covering more than $75,000 \mathrm{~km}^{2}$. Isopachs built for the Dezful Embayment area show more than 5,000-m thick Cenozoic successions in the northeast of the region predominantly consisting of MioceneQuaternary non-marine clastic deposits. Adjacent areas show far thinner synchronous successions, observation that is consistent with the assumption of the Embayment acting as depocentre within the Arabia-Eurasia collision zone. The Oligocene and early Miocene strata (the Asmari limestones and their lateral equivalents) show different subsidence patterns with 600-900 m within the Embayment and only 200-400 m thickness outside it. The Asmari Formation is best developed in the Dezful Embayment Zone. Lithologically, this formation consists of thin, medium to thick, and massive carbonate layers. Some sandstone layers (Ahvaz Member) and anhydrite deposits (Kalhur Member) are also present. The Kalhur evaporite deposits in the Lurestan province and the Ahvaz sandstone deposits southwest of Dezful Embayment are two members of the Asmari Formation. The northeastern boundary of the Dezful Embayment is represented by the Mountain Front Fault, the southwest boundary occurs along anticlines roughly in alignment with Zagros frontal structures to the northwest and southeast (Fig. 1). The eastern limit is marked by the Kazerun Fault, whereas the northern one by the Balarud Line (Fig. 1). The Balarud Line has been mapped as left-lateral strike-slip fault (Hessami et al., 2001). The regional structure is characterized by anticlines that trend NW-SE and plunge towards the Line. Some individual fold traces are E-W deflected as they approach the Line (e.g., Ghale Nar). There is no strong geological, geomorphic or seismic evidence for the presence of an active, emergent fault along the Balarud Line, of whatever motion direction. However, the Balarud Line exerts a strong control on the tips of folds to either side of it, a feature that needs further investigation (Allen and Talebian, 2011). Isopach data show uneven thicknesses of the sedimentary deposits on both sides (Fig. 1), which imply the presence of a step in the 


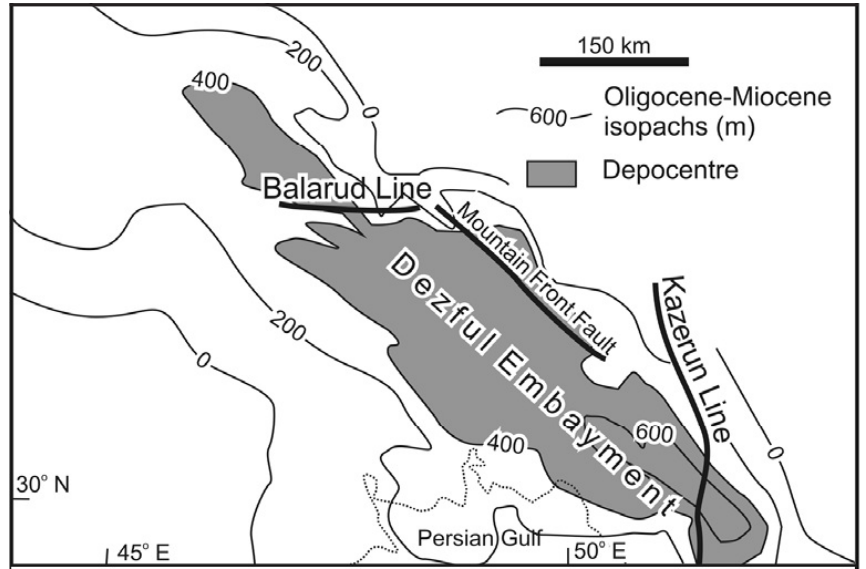

Fig 1. The isopach map of the study area in the Dezful Embayment and the adjacent areas (modified from Koop and Stoneley, 1982 and Motiei, 1993).

basement's profile. The Balarud Line must delimit more deeply buried basement within the Embayment from equivalent rocks to the north (Allen and Talebian, 2011).

Ghale Nar Oilfield, the area under study, is located in the northern area of the Dezful Embayment close to the Balarud Line (Fig. 2). Busk and Mayo (1918) have named the CretaceousEocene sequence in this area the "Asmari Formation", after the Kuh-e-Asmari occurrence in Khuzestan province. This formation was afterwards studied by Richardson (1924) and Van Boeckh et al. (1929). Lees (1933) revised the previous work and has re-assigned the Asmari Formation to the OligoceneMiocene interval. According to Thomas (1948), the age of the formation is Oligocene-Burdigalian. The carbonate sediments of the Asmari Formation in the Zagros Basin are known as Iran's potential reservoir facies. The aim of this study is to interpret the identified facies in the study section (Fig. 2) in terms of sequence stratigraphy and to chronologically calibrate these by using foraminiferal biostratigraphy.

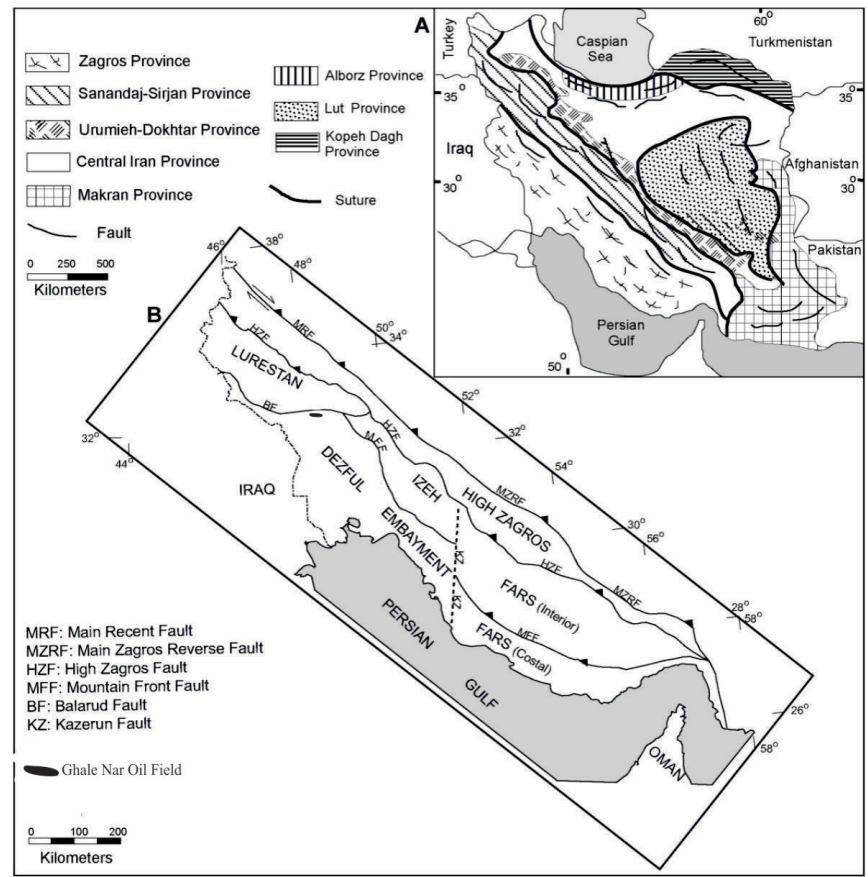

Fig. 2. Location of the study area. a) The general map of Iran illustrating eight geological provinces (adapted from Heydari et al., 2003); b) Subdivisions of Zagros province. Ghale Nar Oilfield is located at the boundary between the Dezful Embayment and the Lurestan zone (adapted from Farzipour-Saein et al., 2009).

\section{GEOLOGICAL SETTING AND PREVIOUS WORKS}

The study area is located southwest of Zagros Mountains (Fig. 2). The region is a young, Miocene-Pliocene fold-thrust belt stretching along the eastern margin of the Arabian Plate. The Zagros fold-and-thrust belt (ZFTB) extends over an area of more than $1800 \mathrm{~km}$, from Kurdistan, north of Iraq, to the Strait of Hormuz in Iran. It resulted from the long-standing convergence between the Eurasian and Arabian plates, during the closure of the Neotethys (Lacombe et al., 2011). According to FarziapourSaein et al. (2009), ZFTB comprises the geographic provinces of Lurestan, Fars and Dezful Embayment. The Zagros foreland exhibits a variety of active depositional environments. From the Arabian plate towards the Zagros Mountains, a transition from sabkha and supratidal environments to carbonate ramp (distal foredeep), marine basin and coastal plain (foredeep) and finally to meandering and braided river systems (wedge-top) can be noticed (Pirouz et al., 2011). According to Sepehr and Cosgrove (2005), after the Permo-Triassic rifting event leading to the JurassicMiddle Cretaceous setting of the Arabian Tethyan margin and the Zagros passive continental margin, the Late Cretaceous tectonic evolution was governed by the obduction of the Tethyan ophiolites onto the Arabian margin. At that time, the basinal Gurpi Formation covered nearly the entire Zagros basin in response to the flexure of the Arabian plate. During the Paleocene-Eocene, the Main Front Fault has isolated two sub-basins within the foreland basin: a shallow one to the NE in which clastic rocks and carbonates accumulated, and a deeper basin to the SW where shales of the Pabdeh Formation were deposited. During the Oligocene, the shallow marine platform limestones of the Asmari Formation deposited unconformably above the Pabdeh Formation in the SW Zagros basin and also covered the Jahrom Formation in the NE Fars region. On their top, the Miocene Fars Group (Gachsaran, Mishan, Agha Jari formations) represents a first-order regressive sequence (up to $3000 \mathrm{~m}$ ) that reflects the progressive infilling of the Zagros foreland basin. In the 1960s, comprehensive studies of the depositional history of the Asmari deposits in the Dezful Embayment have been published (Thomas, 1950; James and Wynd, 1965). More recent publications on the Asmari Formation include Seyrafian (2000) and Vaziri-Moghaddam et al. (2006), the subsurface work on diagenesis by Aqrawi et al. (2006), or the $\mathrm{Sr}$ isotope studies of Ehrenberg et al. (2007), Laursen et al. (2009), and Van Buchem et al. (2010).

\section{MATERIAL AND METHODS}

Ghale Nar Oilfield is located in the north of the Dezful Embayment near the Balarud Line, at the boundary between Dezful Embayment and Lurestan zone, SW Iran). It is located at about $40 \mathrm{~km}$ north of the city of Andimeshk, and the geographical coordinates at the surface are $33^{\circ} 24^{\prime} \mathrm{N}, 48^{\circ} 17^{\prime} \mathrm{E}$ to $33^{\circ} 20^{\prime} \mathrm{N}$, $48^{\circ} 30^{\prime}$ E (Fig. 2).

Our study is based on thin section and facies analysis of the Asmari Formation in one subsurface borehole profile (log) in the Ghale Nar Oilfield. The studied stratigraphic section (Well no. 2) is $5,149 \mathrm{~m}$ deep. Well no. 2 was sampled continuously along most of its depth. Core samples and cuttings were described and placed in wooden core boxes for preservation and storage at the National Iranian South Oil Company (NISOC). The composition of the studied succession was microscopically investigated in transmitted light in more than 300 thin sections $(28 \times 48 \mathrm{~mm})$ obtained from cores samples and cuttings In order to distinguish calcite from dolomite, the thin sections were stained with alizarin 
red. The microfacies distribution is used to interpret the detailed sequence stratigraphy of the Asmari Formation Oligocene (Rupelian-Chattian)-Early Miocene (Burdigalian) sediments. Our methodological approach consisted in:

1- Defining the sedimentary facies and its interpretion from an environmental point of view;

2- Investigating biostratigraphic and paleoecological data in order to understand the sedimentary environment;

3- Analyzing the depositional sequences and establishing the sequence hierarchy (i.e., stacking pattern analysis).

\section{WELL 2, GHALE NAR OILFIELD: STRATIGRAPHY AND AGE}

\section{Stratigraphic succession}

In south-west Iran, Oligocene-Miocene marine sedimentary successions are well represented in the Zagros basin. A445 m-thick stratigraphic section including the topmost Pabdeh Formation (18 m-thick), the Asmari Formation (419 m-thick), and the base of the Gachsaran Formation ( $8 \mathrm{~m}$-thick) was measured in the study area (Fig. 3). The Pabdeh formation (Early Oligocene) consists of marl interlayered with thin-bedded grey to pale green argillaceous limestone. These deposits represent a deep-water marine succession with globigerinids, large and flat lepidocyclinids, and nummulitids. This succession is overlain by bioclastic limestone, dolomitic limestone and dolomite constituting the Asmari Formation. Geographically, the Asmari Formation was deposited on an extended distal middle to proximal carbonate ramp during the Oligocene (Rupelian-Chattian) to the early Miocene interval. This formation is characterized by shallow-water carbonate deposits, $202 \mathrm{~m}$-thick, consisting of wackestone and packestone with robust lepidocyclinids and nummulitids associated with coralline red algae, echinoderms and branched corals in the base. This lithostratigraphic unit is overlain by a $123 \mathrm{~m}$-thick packstone-type limestone with porcelaneous foraminifera (Late Chattian), followed by 27 m-thick carbonate deposits mainly consisting of packestone-grainstone with ooids and foraminifera (Aquitanian). The top of this formation is characterized by a 69 m-thick carbonate succession consisting of wackestone with miliolids and echinoderms (Early Burdigalian). The succession ends with anhydrite and dolomitic beds representing the Gachsaran Formation. Towards its top, the studied log illustrates a full transition from deep to shallow water marine environments.
Based on the microscopic study of the sediment composition, we have separated 14 microfacies types.

\section{BIOZONATION AND DATING}

We have identified 33 genera and 22 species of larger foraminifera in the studied sediments of the Asmari Formation. The fauna, dominated by hyaline perforated and porcellaneous forms, was classified into 4 foraminiferal assemblages, as presented below:

Assemblage 1 was defined starting from the log's base up to $202 \mathrm{~m}$ height within the Asmari Formation succession. The most important and common foraminifers in this assemblageinclude: Eulepidina dilatata (Lemoine and Douville), Eulepidina elephantine (Lemoine and Douville), Nephrolepidina tournoueri (Lemoine and Douville), Heterostegina sp, Operculina complanata (Defrance), Neorotalia viennoti (Greig), Spiroclypeus ranjanae (Tewari), Heterostegina assilinoides (Blanckenhorn). Subordinated foraminifera are: Valvulinid sp., Ditrupa sp. Amphistegina sp., Amphistegina lessonii (d'Orbigny), and Textularia sp.

Assemblage 2 was identified along $121 \mathrm{~m}$ within the succession. Its most diagnostic species include: Austrotrillina asmariensis (Adams), Austrotrillina howchini (Schlumberger), Archaias asmaricus (Smout and Eames), Archaias hensoni (Smout and Eames), Archaias sp., Peneroplis evolutus (Henson), Peneroplis thomasai (Henson), Dendritina rangi (d'Orbigny), Valvulinid sp., Triloculina trigonula (Lamarck), Miogypsinoides complanata (Schlumberger), Miogypsinoides sp., Amphistegina sp. Meandropsina sp. and Meandropsina anahensis (Henson), Meandropsina iranica (Henson). The subordinate foraminifera are Neorotalia viennoti (Greig) and Operculina sp.

Assemblage 3 occurs along $27 \mathrm{~m}$ within the Asmari Formation. The most important foraminifers are represented by: Miogypsina sp., Miogypsina cf. irregularis (Michelotti), Miogypsinoides sp., Peneroplis evolutus (Henson), Peneroplis thomasai (Henson), Austrotrillina howchini (Schlumberger), Ammonia beccarii, Dendritina rangi (d'Orbigny), Valvulinid sp., Elphidium sp.14 (Thomas), Triloculina trigonula (Lamarck), Discorbis sp, and Reusella sp. Subordinate foraminifers include: Spirolina cylindracea (Lamarck), Triloculina tricarinata (d'Orbigny), Meandropsina iranica (Henson), or Austrotrillina asmariensis.

Assemblage 4 characterizes the last $69 \mathrm{~m}$ in the top of the Asmari Formation. The most important benthic foraminifera of this

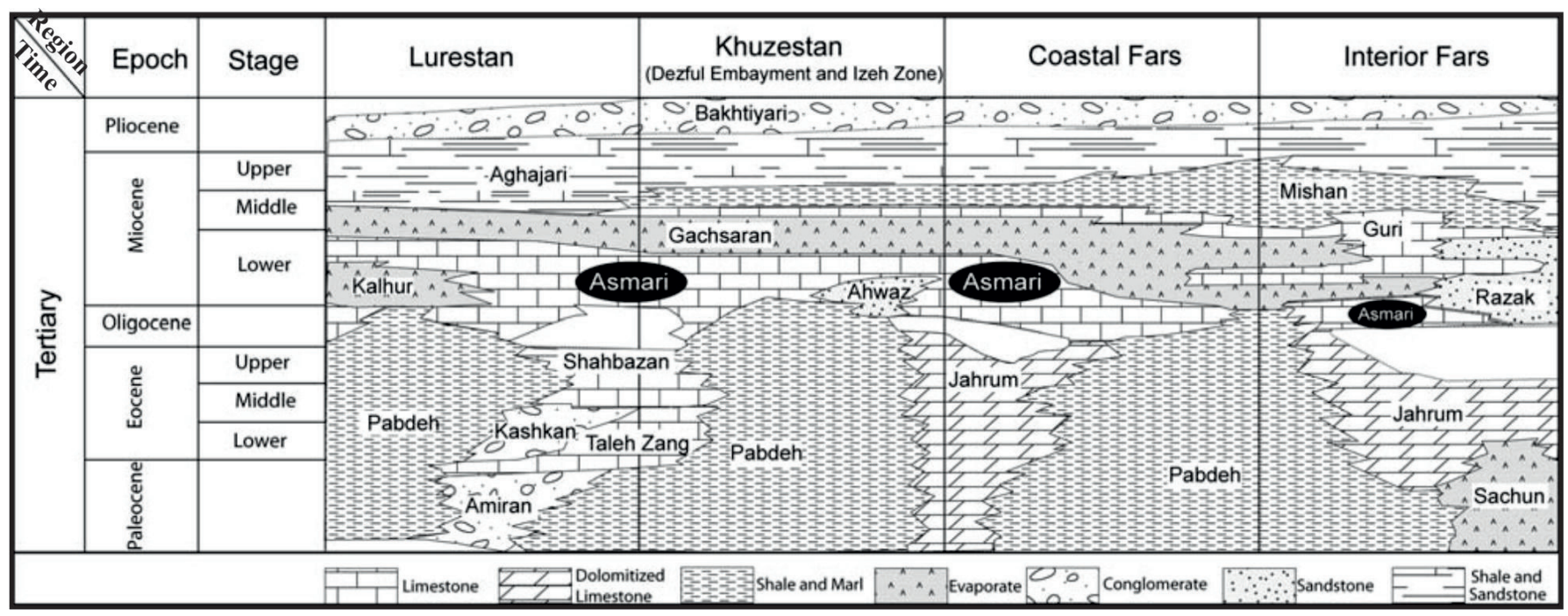

Fig. 3. Cenozoic stratigraphic correlation chart of the Iranian Sector of Zagros Basin (adapted from James and Wynd, 1965). 
assemblage include: Borelis melo curdica (Reichel), Borelis melo melo (Fichtel and Moll), Dendritina rangi (d'Orbigny), Ammonia beccarii (Linne), and the subordinate foraminifers including: Valvulinid sp, Peneroplis evulotus (Henson), Meandropsina iranica (Henson), Elphidium sp. (Thomas), Triloculina trigonula (Lamarck), and Triloculina tricarinata (d'Orbigny).

\section{BIOSTRATIGRAPHY: DISCUSSION}

Wynd(1965)has publishedadetailed biostratigraphical study on the Asmari Formation, whereas Adams and Bourgeois (1967) have revised the previous biostratigraphic data (Table 1). The biozones introduced by Wynd (1965) and Adams and Bourgeois (1967) were widely used throughout the Zagros and Central Iranian basins for the Asmari Formation and its age equivalent Qom Formation, respectively. Cahuzac and Poignant (1997) defined the assemblage zones so that they could be compared to the European basins ones (Table 2). Ehrenberg et al. (2007) conducted strontium isotope dating to improve the biostratigraphic, depositional sequences, and duration of sequences and parasequences ages for the Asmari Formation. These authors introduced five biostratigraphic events based on index fossils, species of Nummulites and Spiroclypeus blankenhorni, genera Miogypsina and Archaias, and species of Borelis melo curdica. Recently, Laursen et al. (2009) have established a new biozonation scheme for the Asmari Formation (Table 3). Based on this new biozonation, the sediments that had been previously assigned to the Miocene (Aquitanian) are currently considered as Late Oligocene (Chattian) in age. Van Buchem et al. (2010) applied Sr isotope dating for the Asmari Formation and proposed revised time intervals based on new biozones: Nummulites vascus - Nummulites fichteli assemblage zone for the Rupelian, Lepidocyclina - Operculina - Ditrupa assemblage zone for the Rupelian-Chattian, Archaias asmaricus - A. hensoni Miogypsinoides complanatus assemblage zone for the Aquitanian, and Borelis melo curdica - Borelis melo melo assemblage zone for the Burdigalian. As previously mentioned, we have identified four foraminifera assemblages within the Asmari Formation in the study area. Accordingly, we assign this formation a RupelianChattian to Early Burdigalian age.

Assemblage 1 occurs above the Globigerina spp. Zone 55 of Wynd (1965) and below the first occurrence of Austrotrillina howchini - Peneroplis evolutus. These foraminifera correspond to the Eulepidina - Nephrolepidina - Nummulites Assemblage Zone3 proposed by Adams and Bourgeois (1967), biozone SB22B of Cahuzac and Poignant (1997), and Lepidocyclina - Operculina Ditrupa Assemblage Zone of Laursen et al. (2009) and Van Buchem et al. (2010). The above-mentioned foraminifera document a Rupelian-Chattian (Oligocene) age for the lower part of the Asmari Formation (Laursen et al., 2009; Van Buchem et al., 2010).

Assemblage 2 corresponds to the Archaias operculiniformis zone, Zone 58 of Wynd (1965), Archaias asmaricus - Archaias hensoni subzone 2B of Adams and Bourgeois (1967), Miogypsinoides - Eulepidina SB23 biozone of Cahuzac and Poignant (1997), and Archaias asmaricus - A. hensoni Miogypsinoides complanatus Assemblage Zone of Laursen et al. (2009) and Van Buchem et al. (2010). The above-mentioned foraminifera document a Chattian (Oligocene) age for this part of the Asmari Formation (Ehrenberg et al., 2007). Assemblage 3 corresponds to the Austrotrillina howchini - Peneroplis evolutus Assemblage Zone 59 of Wynd (1965), Elphidium sp. 14 - Miogypsina subzone 2 of Adams and Bourgeois (1967), biozone SB24 of Cahuzac and Poignant (1997) and Miogypsina - Elphidium sp. 14 - Peneroplis farsensis Assemblage Zone of Laursen et al. (2009) and Van Buchem et al. (2010). The faunal assemblage of this zone suggests an Aquitanian age (Adams and Bourgeois, 1967; Laursen et al., 2009; Van Buchem et al., 2010). Assemblage 4 corresponds to the Borelis melo curdica zone 61 of Wynd (1965), Borelis melo curdica - Meandropsina iranica assemblage Zone 1 of Adams and Bourgeois (1967), biozone SB25 of Cahuzac and Poignant (1997), and Borelis melo curdicaB. melo melo assemblage 11 Zone of Laursen et al. (2009) and Van Buchem et al. (2010), and points to a Burdigalian age (Laursen et al., 2009; Van Buchem et al., 2010).

\section{MICROFACIES AND SEDIMENTARY ENVIRONMENT OF THE INVESTIGATED SEDIMENTS}

Based on the sediments' fabric features and the dominant biotic components, 14 microfacies types were identified in the studied section (Fig. 4a-c).

\section{MF1: Wackestone-packstone with planktonic foraminifera}

This facies is characterized by the presence of planktonic foraminifers, mainly represented by globigerinids. It consists of a fine-grained matrix wackestone. The facies occurs in the top of the Pabdeh Formation (Fig. 4a, 1).

\section{MF2: Bioclastic wackestone-packstone with planktonic foraminifera, lepidocyclynidae, nummulitidae, and corallinaceans}

This facies is characterised by coarse-grained wackestonepackstone dominated by planktonic foraminifera, corallinacean algae

Table 1. Biozonation of the Asmari Formation (modified after Adams and Bourgeois, 1967).

\begin{tabular}{ll}
\hline Age & Biozone \\
\hline Burdigalian & Borelis melo + M. iranica \\
Late Aquitanian & Miogypsinoides + Archaias + Valvulinid( Miogypsina + Elphidium sp 14 sub biozone) \\
Early Aquitanian & Miogypsinoides + Archaias + Valvulinid(Archaias hensoni + Archaias asmaricus sub biozone) \\
Oligocene & Elphidium + Nephrolepidina + Nummulites \\
\hline
\end{tabular}

Table 2. Biozonation of the Oligocene-early Miocene sediments based on the distribution of larger benthic foraminifers (after Cahuzac and Poignant, 1997).

\begin{tabular}{lll}
\hline Age & Biozone & No. \\
\hline Burdigalian & Borelis melocurdica + Miogypsina & Sb25 \\
Aquitanian & Sustrillina howchini + Miogypsina + M.deharti & Sb23 \\
Chatian & Miogypsinoides + Eulepidina & SB22B \\
Chatian & Nummulites vascus + Nummulites fichteli + Eulepidina \\
Rupelian & Eulepidina formosoides & SB21 \\
Rupelian & Nummulites vascus + Nummolites fichteli \\
\hline
\end{tabular}


Table 3. Recently defined biozones by Laursen et al. (2009) on the basis of Sr isotope dating.

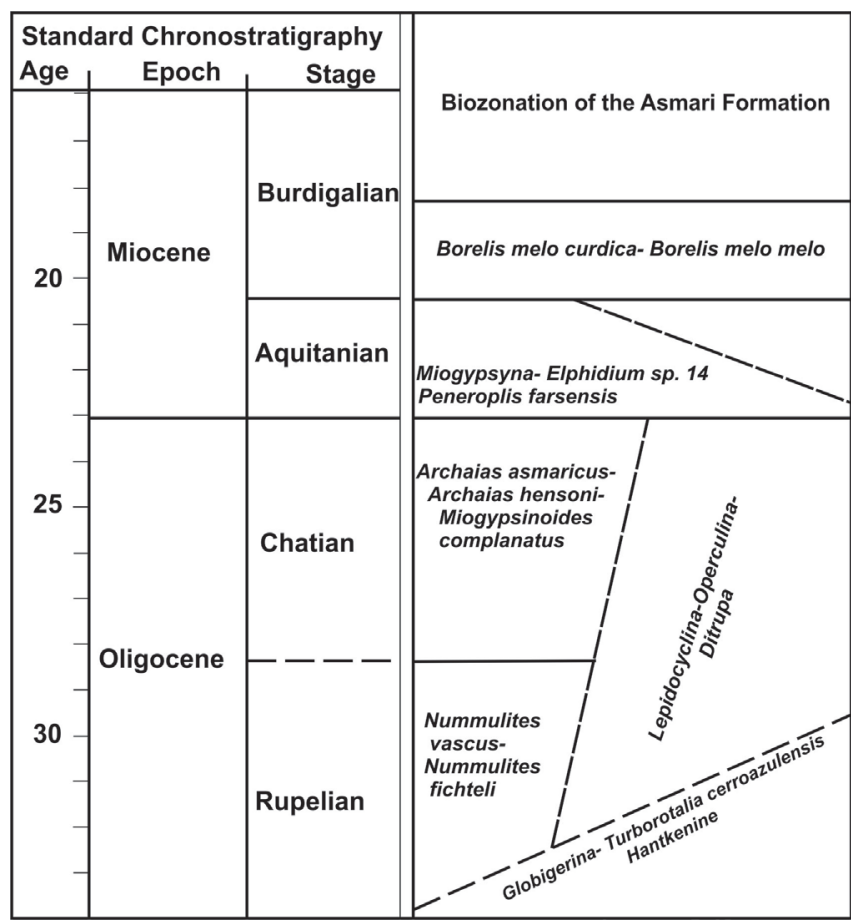

and large benthic foraminifera. Planktonic foraminifers are represented by globigerinids. The larger foraminifera consist of common small lens-shaped nummulitidae, lepidocyclinidae, and Amphistegina spp. In addition, fragments of echinoids occur in minor amounts. This facies occurs in the base of the Asmari Formation (Fig. 4a, 2).

MF3: Wackestone-packstone with echinoids, corals, and corallinaceans

This facies consists of bioclastic wackestones and subordinate packstones containing significant amounts of corallinacean and echinoid fragments. Other bioclasts such as bryozoan, mollusca, miliolids and textularids are very rare. This facies is interlayered with MF2 (Fig. 4a, 3).

\section{MF4: Packstone-grainstone with Favreina}

This facies is dominated by favreinid pelloids; additionally, abundant simple micritic peloids and rare smaller benthic foraminifera and rare echinoid debris are also present. This facies is interlayered with MF5 and MF7 (Fig. 4b, 1).

\section{MF5: Packstone-grainstone with ooids}

This facies consists of abundant ooids; common benthic foraminifera (mainly miliolids, some calcite-cemented agglutinated types, some hyaline types) are also present. This facies is interlayered with MF4 (Fig. 4b, 2).

\section{MF6: Bioclastic packstone with corallineaceans and corals floatstone-rudstone}

This facies is dominated by large coral debris with encrusting coralline algae; some coralline algal debris, rare porcelaneous foraminifera including rare fragments of larger hyaline forms and rare bryozoan debris were also identified within the carbonate
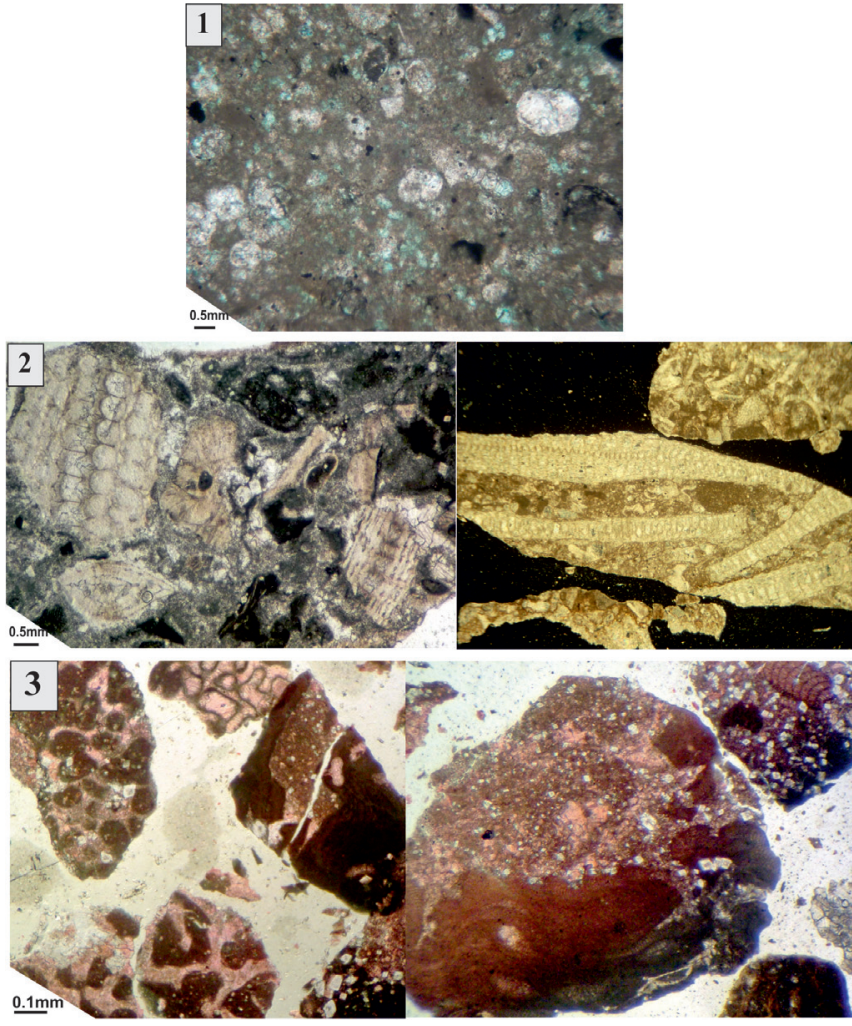

Fig. 4a. 1) Wackestone-packstone with planktonic foraminifera (Pabdeh Formation). 2) Bioclastic wackestone-packstone with planktonic foraminifera, lepidocyclynidae, nummulitidae and corallinaceans. 3) Echinoid coral corallinacean wackestone- packstone.
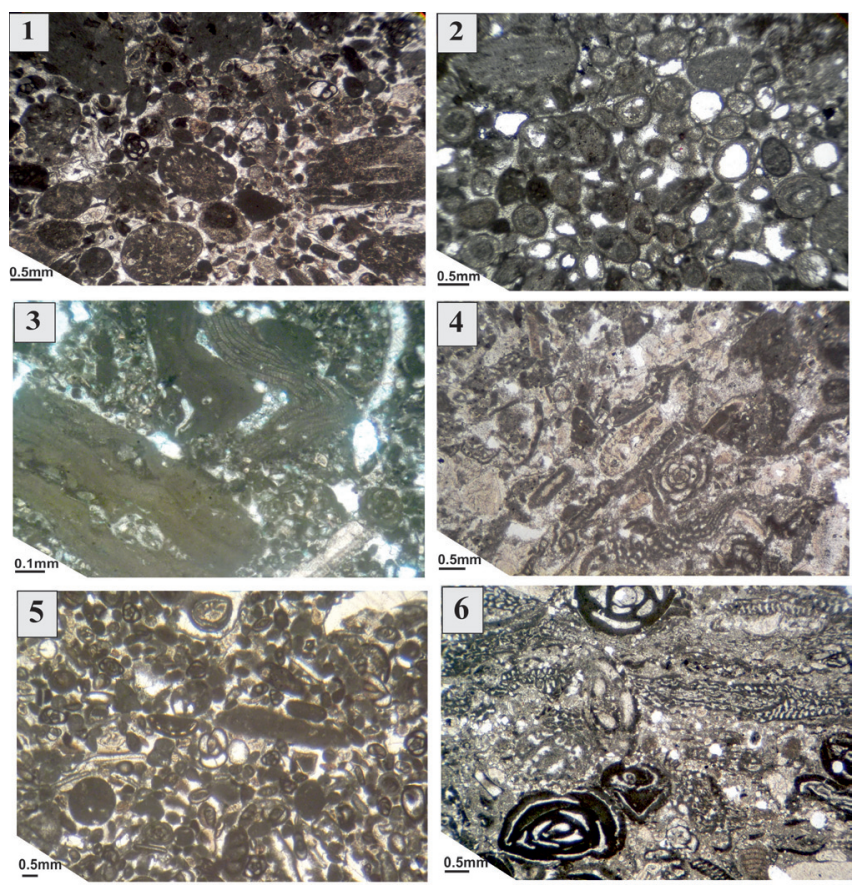

Fig. 4b. 1) Packstone-grainstone with Favreina. 2) Packstone-grainstone with ooids. 3) Bioclastic packstone with corals and coralineaceans/ floatstone-rudstone. 4) Packstone- grainstone with benthic (hyaline and porcelaneous) foraminifera. 5) Peloidal packstone-grainstone with benthic foraminifera. 6) Bioclastic packstone-grainstone with a high diversity of imperforate foraminifera. 
mud matrix. This facies is $6 \mathrm{~m}$-thick and it is interlayered with MF7, MF8, and MF9 (Fig. 4b, 3).

MF7: Packstone-grainstone with benthic (hyaline and porcelaneous) foraminifera

Porcelaneous foraminifera such as miliolids (Austrotrillina, Pyrgo, Quinqueloculina and Triloculina), Archaias, Peneroplis, Dendritina and hyaline foraminifera (Heterostegina, Neorotalia, Elphidium and Miogypsina) are abundant within the MF 7. Fragments of corallinacean red algae, echinoid, and bryozoansare are also present. MF 7 has mostly a grain-supported matrix with micritic groundmass. This facies is $65 \mathrm{~m}$-thick and it is interlayered with MF6 and MF8 (Fig. 4b, 4).

\section{MF8: Peloidal packstone-grainstone with benthic foraminifera}

The main elements of the MF 8 facies are represented by both skeletal and non-skeletal components. Skeletal components comprise porcelaneous benthic foraminifera (Archaias, miliolids and Dendritina), while peloids represent the dominant nonskeletal elements. Perforated foraminifera such as Amphistegina and Elphidium are rare. This facies is $16 \mathrm{~m}$-thick and it is interlayered with MF4, MF6, and MF7 (Fig. 4b, 5).

\section{MF9: Bioclastic packstone-grainstone with a highly diverse} association of imperforate foraminifera

This facies consists of $11 \mathrm{~m}$-thick packestone-grainstone containing a high diversity of imperforate foraminifera (Archaias, Borelis, Meandropsina, Peneroplis, Austrotrillina, Dendritina and miliolids), as well as skeletal fragments of echinoids, bryozoans, and dasycladacean algae. Peloids are also present. This facies is interlayered with MF7 and MF6 (Fig. 4b, 6).

\section{MF10: Wackestone with small rotaliids and echinoids}

This facies is characterised by the abundant presence of smaller rotaliids and echinoids. In addition, Discorbis, miliolids, ostracods and peloids occur in minor amounts. Grains of detrital quartz are also present. The bioclasts are embedded in grey, micritic matrix. This facies is $28 \mathrm{~m}$-thick and it is located in the top of the Asmari Formation. It is interlayered with MF14 (Fig. 4c, 1).

\section{MF11: Bioclastic wackestone with miliolids}

The main allochems of this microfacies are represented by miliolids, Dentririna, Borelis, and skeletal fragments of molluscs. This facies is interlayered with the MF10 facies (Fig. 4c, 2).

\section{MF12: Packstone-grainstone with fecal pellets}

The main components of this microfacies are abundant peloids; very rare benthic foraminifera are also present. This 2 m-thick facies is located in the middle part of the Asmari Formation and it is interlayered with MF13 and MF14 (Fig. 4c, 3).

\section{MF13: Wackestone-packstone with intraclasts}

This facies is characterised by the presence of abundant intraclasts, rare to common pelloids and rare small angular quartz grains. This facies is interlayered with MF8, MF12, and MF14 (Fig. 4c, 4).

\section{MF14: Mudstone}

In this facies type fossils are rare, although mainly sparse fragments of miliolids and echinids are present. Occasionally, very fine quartz grains are scattered within the matrix. This facies is $33 \mathrm{~m}$-thick and it is interlayered with MF13, MF10, and MF13 (Fig. 4c, 5).
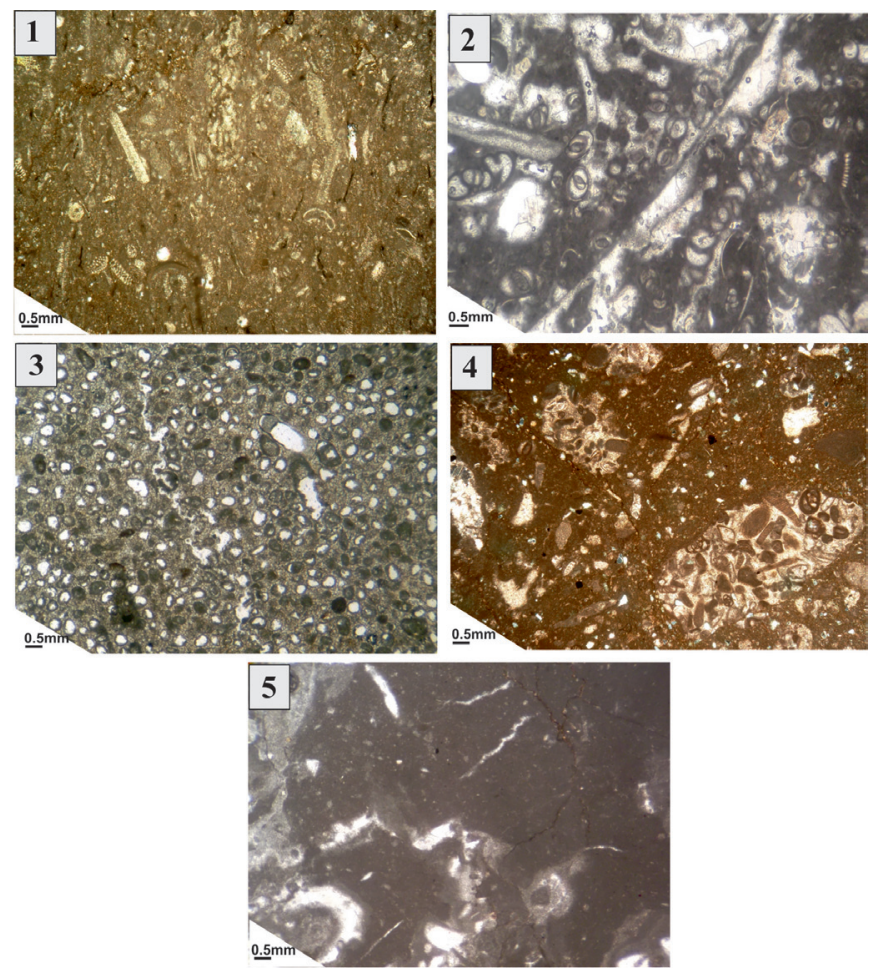

Fig. 4c. 1) Wackestone with small rotaliids and echinoids. 2) Bioclastic wackestone with miliolids. 3) Packstone-grainstone with fecal pellets. 4) Wackestone-packstone with intraclasts. 5) Mudstone.

\section{INTERPRETATION}

The presence of planktonic foraminifers suggests that facies 1 was deposited in a calm and deep environment with dominant normalsalinity water (Wilson, 1975; Buxton and Pedley, 1989; Flugel, 2004). The middle shelf setting can be divided into proximal and distal parts. The proximal middle shelf contains an assemblage dominated by corallinaceans, lepidocyclinidae and nummulitidae with robust and ovate tests. The distal middle shelf facies contains diverse foraminiferal assemblages and textures reflecting an increase in water depth. The distal middle shelf facies types are differentiated from the proximal middle shelf ones by the greater amount of micritic matrix and an increase in the flatness and size of the perforate foraminifera. High taxonomic diversity of perforate foraminifers, corallinaceans, echinoids, bryozoans, mud micrite matrix as well as the stratigraphic position suggests the deposition of facies 2 in a shallower slope environment (Amirshahkarami et al., 2007). The abundance of deep living larger foraminifera (large and flat nummulitids and lepidocyclinids) and the presence of typical open marine skeletal fauna including echinoids and corallinaceans suggest sedimentation in the middle shelf's oligophotic zone (Geel, 2000; Bassi et al., 2007; Brandano et al., 2009). The red algae association and larger benthic foraminifera (facies 3 ) were identified as living in the oligophotic zone of the middle ramp environment (Pomar, 2001; Brandano and Corda, 2002; Corda and Brandano, 2003). Moreover, these foraminifera (mainly Heterostegina and Amphistegina) live in a tropical-subtropical environment over a wide bathymetric range, but are particularly frequent between depths of 40 and $70 \mathrm{~m}$ (Hallock and Glenn, 1986). Accordingly, facies 3 formed in an open marine environment under normal marine salinity conditions, with open water circulation and medium hydrodynamic energy. This interpretation is supported by the stratigraphic position and abundance of typical open marine skeletal fauna including corallinaceans and echinoids. The 
features of facies 4 and 5 indicate moderate to high energy shallow waters with intense movement and reworking of bioclasts and the production of ooids and Faverina. These sediments are interpreted as having been deposited in sand shoals (Wilson, 1975; Flügel, 2004). The presence of the well-preserved red corallinacean algae in facies 5 points to a relatively quiet sedimentary environment with low deposition rate on a stable platform (Nebelsick and Bassi, 2000). The presence of the miliolids associations within MF 6 additionally supports its affiliation to a relatively protected environment, probably in an inner part of a platform (Fournier et al., 2004). The porcelaneous foraminifera associated with Bioclastic packstone with corallineaceans and corals floatstonerudstone facies is typical of shallow and illuminated habitats where sea grass flats intersect adjacent non-vegetated areas (Brandano et al., 2008). Moreover, scattered branching corals are typical for areas with reduced water energy located in the lowest part of the euphotic zone (Schuster and Wielandt, 1999). However, the common coral debris may have derived from adjacent patch reefs or could also have been produced in situ from isolated colonies that are known to grow in sea grass environments (Brasier, 1975). The co-occurrence of normal marine (corallinacean and perforate foraminifera) and platform interior (imperforate foraminifera) biota in facies 7 indicates that sedimentation took place in a shelf lagoon and suggests that no effective barrier existed (Romero et al., 2002). A similar facies with imperforated foraminifers, perforated foraminifers and corallinaceans was reported from an inner ramp in the Miocene sediments of the Central Apennines (Corda and Brandano, 2003), and from Early Oligocene deposits of the Lower Inn Valley (Nebelsick et al., 2001). This association, together with the presence of the red algae debris characterizes an inner-shelf depositional setting (Corda and Brandano, 2003). In facies 8 , the skeletal components and the grainstone textural rock type are interpreted as results of a high-energy environment with high salinity water (40 psu salinity range) (Mossadegh et al., 2009). Additionally, the presence of sparry calcite cement is also indicative of a high-energy environment. Textural characteristics and prolific porcelaneous foraminifera, as well as peloids, suggest that a high-energy portion of a restricted lagoon with a nearby tidal flat sedimentary environment prevailed (Vaziri-Moghaddam et al., 2006). A similar facies was studied by Brandano et al. (2008) from a grass-dominated inner ramp setting as suggested by the presence of epiphytic foraminifera such as Archaias and Dendritina. The depositional textures, the fauna and the lack of general features representative of emergent conditions, support the interpretation of facies 8 and 9 as being deposited in warm euphotic, shallow water, within an inner shelf setting. This interpretation is supported by the presence of abundant and diverse imperforate foraminifera (Geel, 2000; Corda and Brandano, 2003; Vaziri-Moghaddam et al., 2006; Bassi et al., 2007). Facies 10 was deposited in a marinerestricted environment. The low faunal diversity (small rotaliids and echinoids) confirms this interpretation. The predominance of mudrich textures with miliolids, and the presence of a low-diversity foraminiferal association in facies 11 indicate a restricted platform, very shallow lagoon with low hydraulic energy (Geel, 2000). The presence of poorly-sorted, silt-sized detrital quartz within the wackestone-packstone with intraclasts (facies 13) suggests a sedimentary environment in the proximity of the continent. In facies 14, the appearance of sparse fine-grained quartz together with echinoid fragments, ostracods and miliolids within a micritic groundmass is typical for restricted inner lagoon environments (Rasser et al., 2005). This facies is also similar to the SMF19 of Wilson (1975) and is characteristic for the facies belts 8 and 9 of a near-coast platform interior setting (Flugel, 2004). This facies is interpreted as representing very shallow lagoonal to lower intertidal deposits (Wilson and Evans, 2002).

\section{SEDIMENTARY MODEL}

The facies distribution as well as the presence of larger benthic foraminiferal and coralline red algal assemblages suggest that the depositional profile of the studied sediments is consistent with a ramp model. Burchette and Wright (1992) subdivided ramp depositional systems based on the fair weather wave base (FWWB) and the storm wave base (SWB). According to the microfacies distribution, four general zones can be distinguished along such a ramp: (1) a proximal inner ramp setting (within the fair FWWB) occupied in our case by facies types $8,9,10,11,12,13$, and 14; (2) a distal inner ramp/ proximal middle ramp transitional setting represented by facies $4,5,6$, and 7 . These facies types are located under constant wave-agitated environments across the FWWB, within the distal inner-/proximal middle ramp; (3) a proximal mid-ramp setting, represented here by facies 3 suggests deposition in an environment below the FWWB; (4) a distal midramp/ proximal outer ramp setting (below the FWWB, near the SWB) represented by our facies types 1 and 2 . According to the larger foraminiferal distribution, the inner and middle/proximal outer ramp was differentiated in a ramp gradient ranging from: (1) a proximal inner ramp setting characterized by Archaias, Borelis, Austrotrillina, Triloculina, Peneroplis, Meandropsina, (2) the deeper part of the inner ramp with Neorotalia, Miogypsinoides, Miogypaina, and Amphistegina (representing the transition to the following zone), to (3) a proximal middle ramp setting dominated by coralline red algae, corals with Nummulitidea, and (4) a distal middle ramp/proximal outer ramp setting dominated by Nummulitidea, Lepidocyclinidae, and globogerinids. This ramp depositional model corresponds to similar Eocene and Miocene ramp models published by Brandano and Corda (2002), Corda and Brandano (2003), or Brandano et al. $(2008,2010)$.

\section{SEQUENCE STRATIGRAPHY}

Each sequence consists of a package of transgressive and regressive sedimentary facies (systems tracts or facies tracts) and is bracketed by two sequence boundaries (Wanas, 2008). In marine shelf homogeneous carbonate environments, it is sometimes difficult to distinguish between the different system tracts of a depositional sequence (Posamentier and Vail, 1988; Sarg, 1988). Hence, the various markers of high and low sealevel phases, such as benthic foraminifera, seem to provide particularly reliable data as they are very sensitive to any change in the environment (Vaziri-Moghaddam et al., 2006). In our case study the facies distribution, stratal patterns, and sequence boundaries permit the identification of four separate third-order depositional sequences, occurring at particular stages during the Oligocene-Miocene interval (Figs. 5, 6). Each thirdorder depositional sequence is composed of one transgressive systems tract (TST), one highstand systems tract (HST), and one maximum flooding surface (MFS).

Our sequence stratigraphic interpretation was constructed by using an integrated dataset including: (1) biozonation; and (2) the environmental interpretation of depositional facies based on sedimentological and micropaleontological observations. Van Buchem et al. (2010) proposed a regional sequence stratigraphic model for the Oligocene-Miocene Asmari and Pabdeh Formations in the Dezful Embayment of SW Iran. 
The model is based on both new detailed sedimentological observations in outcrops, core and well logs, and an improved high-resolution chronostratigraphic framework constrained by $\mathrm{Sr}$ isotope stratigraphy and biostratigraphy. The authors have distinguished three Oligocene (Rupelian, Early Chattian, and Late Chattian in age) and three Miocene (Early Aquitanian, Late Aquitanian, and Early Burdigalian in age) sequences, covering a period of 15.4 Ma. These sequences have been cross-correlated from platform to basin through 50 control points in the study area (300-350 km), which allowed unravelling the complex 3D geometrical and lithological organization of this OligoceneMiocene sedimentary system. These six sequences vary in duration from 1.2 to $5.2 \mathrm{Ma}$, classifying them as third order (Table 4). In this study, to better match the identified sequences with those of the Asmari Formation in the Dezful Embayment and Izeh zone (which have absolute ages; Van Buchem et al., 2010), their number is used as their name. Sequence 1 is located within the Pabdeh Formation, but sequences 2 to 6 have been identified within the Asmari Formation.

\section{Sequence 2 (Late Rupelian-Early Chattian)}

Sequence 2 includes the upper part of the Pabdeh Formation and the lower part of the Asmari Formation. TST was clearly recognized in this area. The marly limestones and limestones of the TST contain wackestone-packstone with planktonic foraminifera (MF1) and bioclastic wackestone-packstone with planktonic foraminifera, Lepidocyclynidae, nummulitidae, and corallinaceans (MF2). The distal middle shelf facies contains relatively large amounts of micritic matrix and illustrates an increase in the flatness and size of the perforate foraminifera, thus documenting a deep, low energy environment during the TST. The maximum flooding surface (MFS) is indicated by the MF1. The highstand systems tract (HST) is represented by the: i) MF2 (the proximal middle shelf contains an assemblage dominated by corallinaceans, lepidocyclinidae, and nummulitidae with robust and ovate tests), ii) the wackestone with echinoids, corals, and corallinaceans (MF3) suggesting open marine, medium hydrodynamic energy environmental conditions, iii) the packstone-grainstone with (hyaline and porcelaneous) foraminifera (MF7), and iv) the bioclastic packstone-grainstone with a high diversity of imperforate foraminifera (MF9). The last HST shows a trend toward shallower sediments.

\section{Sequence 3 (Late Chattian)}

An increase in the third-order accommodation space is indicated by shallow lagoonal facies (MF9) overlain by a deeper facies, i.e., the bioclastic packstone with corals

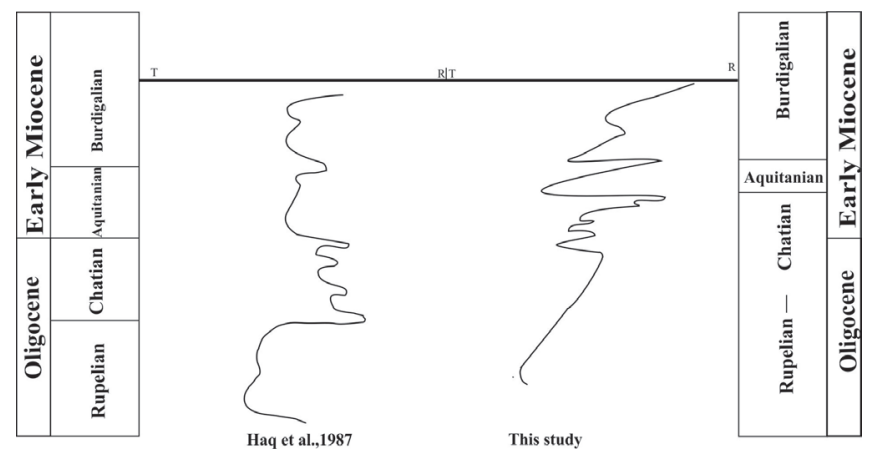

Fig. 5. Correlation between the relative sea-level change curves in the study area and the global model for the Oligocene-Miocene (Haq et al., 1987).
Table 4. The number and the age of the identified sequences in Dezful Embayment and Izeh zone (Van Buchem et al., 2010).

\begin{tabular}{|c|c|c|}
\hline NO & \multicolumn{2}{|c|}{ Age } \\
\hline 6 & Early Burdigalian & \multirow{2}{*}{ Miocene } \\
\cline { 1 - 2 } 5 & Late Aquitanian & \\
\hline 4 & Early Aquitanian & \multirow{2}{*}{ Oligocene } \\
\hline 3 & Late Oligocene & \\
\hline 2 & Early Oligocene \\
\hline 1 & Rupelian & \\
\hline
\end{tabular}

and corallineaceans/floatstone-rudstone (MF6). The MFS is marked by the MF6 (packstone). On its top, the HST is represented by i) the MF7, the peloidal packstone-grainstone with benthic foraminifera (MF8), ii) the bioclastic packstonegrainstone with a high diversity of imperforate foraminifera (MF9), iii) the bioclastic wackestone with miliolids (MF11), iv) the packstone-grainstone with fecal pellets (MF12), and v) the mudstone (MF14). These facies types have been deposited in a shallow- to very shallow lagoonal-lower intertidal environment. The upper limit of sequence 3 (SB 2) is almost coincident with the Chattian-Aquitanian boundary, which can be correlated with the fall of the eustatic sea level as indicated by Haq et al. (1987) (Figs. 5, 6).

\section{Sequences 4 and 5 (Early-Late Aquitanian)}

Following the very shallow subtidal depositional environment of the top of sequence 3 , the sea deepened, leading to the deposition of the sandy shoal facies types (MF4, MF5), which represent the TST. The overlying packstone-grainstone with diverse fauna reflects a MFS and the beginning of the deposition of a HST. The overlying MFS, rich in imperforate foraminifera (MF8), as well as the MF13 and MF14 have been deposited in a shallow- to very shallow lagoonal-lower intertidal environment; this part is interpreted as a HST.

\section{Sequence 6 (Early Burdigalian)}

The TST package of sequence 6 consists of sediments deposited in restricted and semi-restricted lagoonal environments. The TST is characterized by the MF7 and MF8. The HST suggests a shallowing upward trend with transition into a restricted (MF10 and MF11) to near-shore lagoonal environment. HST ends with a near-shore lagoonal facies (MF 14).

Four sequence boundaries were identified for the Asmari Formation in the study area. Sequence boundary that presents at the base of the sequence $4+5$, near the Chattian -Aquitanian border, is close to Aq. 10 of global regressive sea level (Gradstein et al., 2004) and is coincident with basal Kalhur anhydrite in the Dezful Embayment (Ehrenberg et al., 2007). It can be referred to as an index sequence boundary within the Chattian-Aquitanian carbonate successions of the Asmari Formation in the Zagros Basin (Fig. 7). Sequence boundary that presents at the base of sequence 6 at the Aquitanian-Burdigalian border is close to $\mathrm{Bu}$ 20 of global regressive sea level (Gradstein et al., 2004) and is coincident with the top of middle Kalhur anhydrite in the Dezful Embayment (Ehrenberg et al., 2007). 

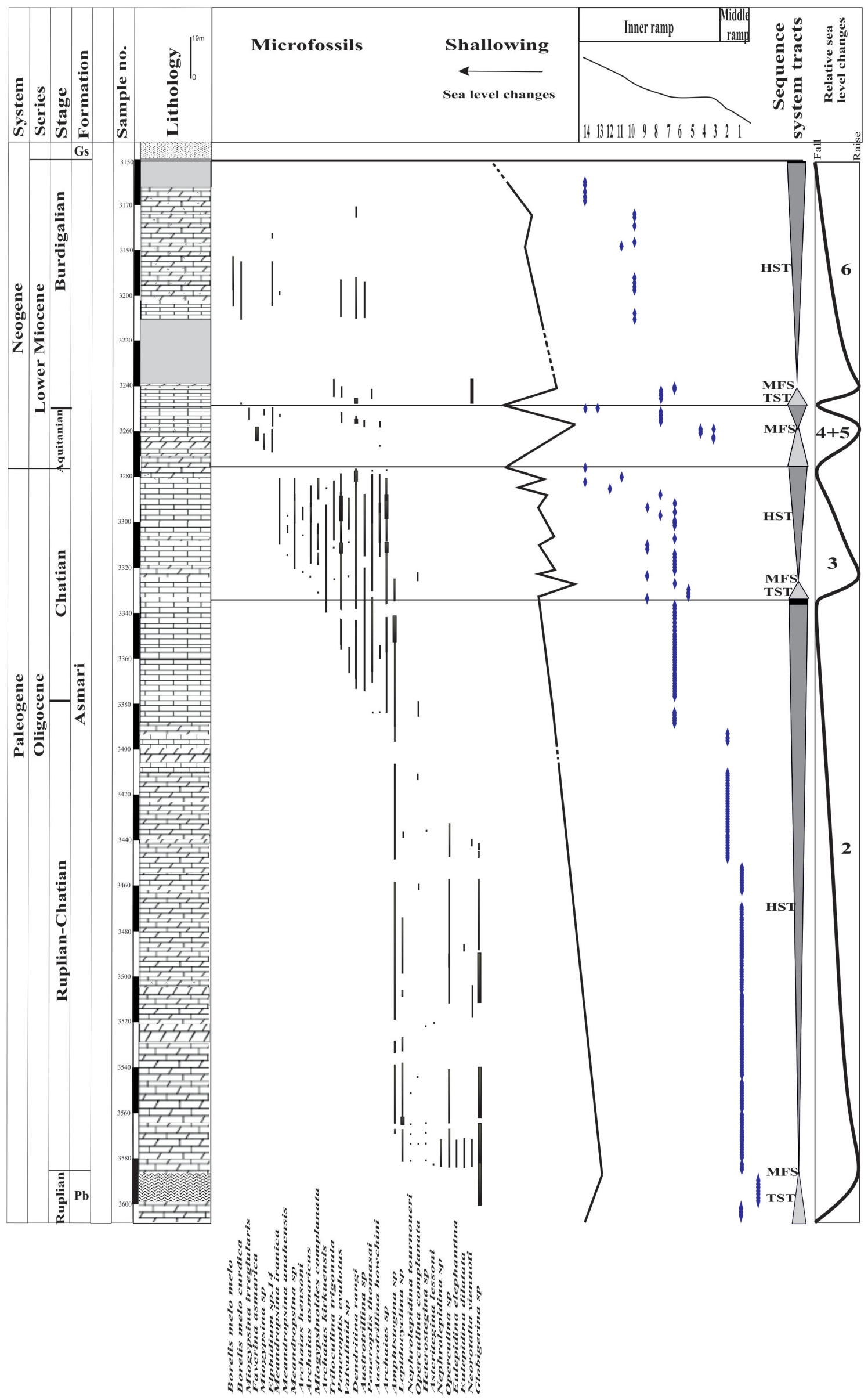

Fig. 6. Stratigraphic column of the Asmari Formation in the studied section reflecting paleoenvironmental, relative sea-level changes and sequence stratigraphic and biostratigraphic details in Gale Nar Oilfield, Zagros Basin. 


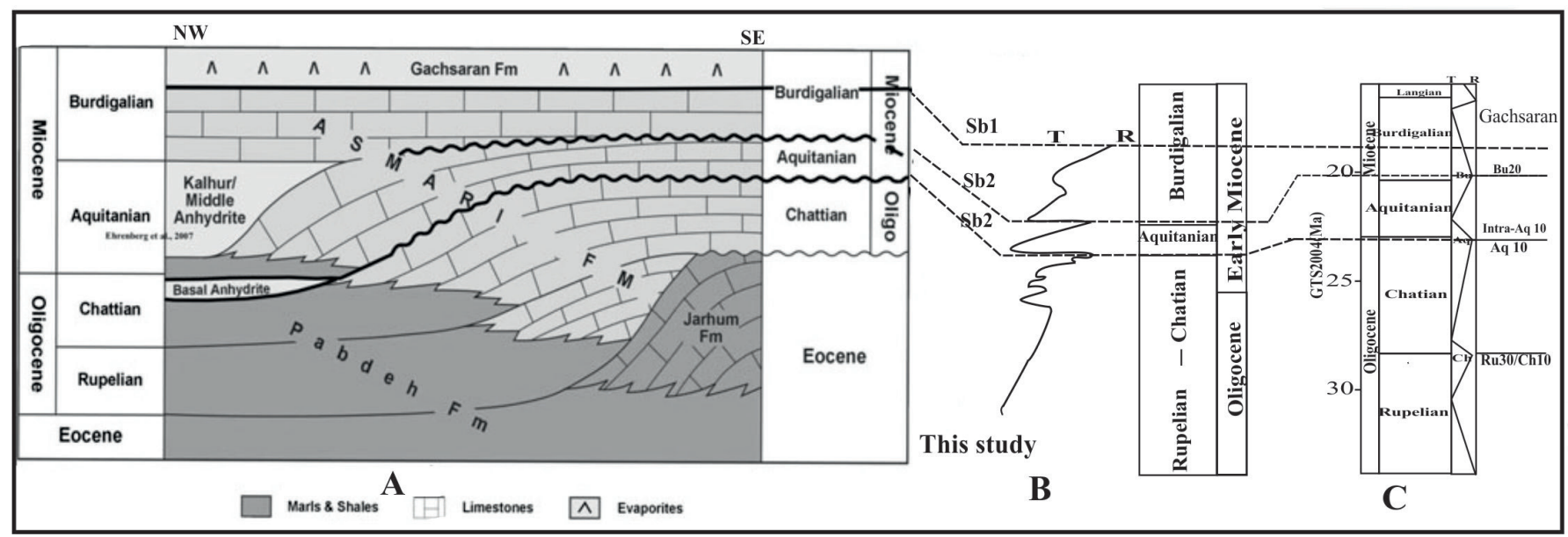

Fig. 7. A-C: Stratigraphic correlation of the Asmari Formation in the studied section with other outcrops in Zagros basin (A) (modified after Ehrenberg et al., 2007); (B) the sequence boundaries of the formation in the study area; (C) the global transgression-regression (T and $R$, respectively) curve proposed by Gradstein et al. (2004).

\section{CONCLUSIONS}

The depositional environments and the sequence stratigraphy of the Oligocene (Rupelian-Chattian)-Early Miocene (Burdigalian) sediments of the Asmari Formation were interpreted based on facies analysis and the identified foraminiferal associations. Fourteen facies types within a shallowing upward cycle, representing open marine, shoal, semi-restricted, restricted lagoonal and near-shore lagoon environments were identified. The environmental interpretations show that the inner and middle parts of a homoclinal ramp were persisting during the deposition of the Asmari Formation. Moreover, relative sea-level change curves were determined and correlated with global sealevel change curves (Haq et al., 1987) during the OligoceneMiocene interval. Four third-order depositional sequences were recognized and the sequence boundaries were correlated with those in the Dezful Embayment of Zagros Basin.

\section{REFERENCES}

Adams, T.D., Bourgeois, F. 1967, Asmari Biostratigraphy, Unpublished Report 1074, Tehran, Iranian Oil Operating Companies, Geological and Exploration Division.

Allen, M.B., Talebian, M. 2011, Structural variation along the Zagros and the nature of the Dezful Embayment. Geological Magazine, 148: 911-24.

http://dx.doi.org/10.1017/S0016756811000318

Amirshahkarami, M., Vaziri-Moghaddam, H. \& Taheri, A. 2007, Sedimentary facies and sequence stratigraphy of the Asmari Formation at Chaman-Bolbol, Zagros Basin, Iran. Journal of Asian Earth Science, 29: 947-959.

http://dx.doi.org/10.1016/j.jseaes.2006.06.008

Aqrawi, A.A.M., Keramati, M., Ehrenberg, S.N., Pickard, N., Moallemi, A., Svna, T., Darke, G., Dickson, J.A.D. \& Oxtoby, N.H. 2006, The origin of dolomite in the Asmari Formation (Oligocene- early Miocene), Dezful Embayment, SW Iran. Petroleum Geology, 29: 381-402. http://dx.doi.org/10.1111/j.1747-5457.2006.00381.x

Bassi, D., Hottinger, L. \& Nebelsick, J.H. 2007, Larger foraminifera from the Upper Oligocene of the Venetian area, North-East Italy. Paleontology, 50 (4): 845-868. http://dx.doi.org/10.1111/j.1475-4983.2007.00677.x
Brandano, M., Corda, L. 2002, Nutrients, sea level and tectonics: constrains for the facies architecture of a Miocene carbonate ramp in central Italy. Terra Nova, 14: 257-262. http://dx.doi.org/10.1046/j.1365-3121.2000.00419.x

Brandano, M., Frezza, V., Tomassetti, L. \& Pedley, M. 2008, Facies analysis and paleoenvironmental interpretation of the Late Oligocene Attard Member (Lower Coralline Limstone Formation), Malta. Sedimentology, 56 (4): 11381158. http://dx.doi.org/10.1111/j.1365-3091.2008.01023.x

Brandano, M., Frezza, V., Tomassetti, L. \& Cuffaro, M. 2009, Heterozoan carbonates in oligotrophic tropical waters: the Attard member of the lower coralline limestone formation (Upper Oligocene, Malta). Palaeogeography, Palaeoclimatology, Palaeoecology, 274: 54-63. http://dx.doi.org/10.1016/j.palaeo.2008.12.018

Brandano, M., Morsilli, M., Vannucci, G., Parente, M., Bosellini, F. \& Mateu-Vicens, G. 2010, Rhodolith-rich lithofacies of the Porto Badisco Calcarenites (upper Chattian, Salento, southern Italy). Italian Journal of Geosciences (Bollettino della Società Geologica Italiana), 129 (1): 119-131.

Brasier, M.D. 1975, An outline history of sea-grass communities. Paleontology, 18: 681-702.

Burchette, T.P., Wright, V.P. 1992, Carbonate ramp depositional systems. Sedimentary Geology, 79: 3-57. http://dx.doi.org/10.1016/0037-0738(92)90003-A

Busk, H.G., Mayo, H.T. 1918, Some notes on the geology of the Persian Oilfields. Journal of Petroleum Technology, 5: 5-26.

Buxton, M.W.N., Pedley, H.M. 1989, Short Paper: A standardized model for Tethyan Tertiary carbonate ramps: Journal of the Geological Society, 146: 746-748. http://dx.doi.org/10.1144/gsjgs.146.5.0746

Corda, L., Brandano, M. 2003, Aphotic zone carbonate production on a Miocene ramp, entral Apennines, Italy. Sedimentary Geology, 161: 55-70. http://dx.doi.org/10.1016/S0037-0738(02)00395-0

Ehrenberg, S.N., Pickard, N.A.H., Laursen, G.V., Monibi, S., Mossadegh, Z.K., Svn, T.A., Aqrawi, A.M. \& Thirlwall, M.F. 2007, Strontium isotope stratigraphy of the Asmari Formation (Oligocene- early Miocene), SW Iran. Journal of Petroleum Geology, 30: 107-128.

http://dx.doi.org/10.1111/j.1747-5457.2007.00107.x 
Farzipour-Saein, A., Yassaghi, A., Sherkati, S. \& Koyi, H. 2009, Basin evolution of the Lurestan region in the Zagros fold-andthrust belt, Iran. Journal of Petroleum Geology, 32: 5-19. http://dx.doi.org/10.1111/j.1747-5457.2009.00432.x

Flügel, E. 2004, Microfacies of carbonate rocks, analysis, interpretation and application. Springer-Verlag, Berlin, $976 \mathrm{p}$.

Fournier, F., Montaggioni, L. \& Borgomano, J. 2004, Paleoenvironments and high-frequency cyclicity from Cenozoic South-East Asian shallow-water carbonates: a case study from the Oligo-Miocene buildups of Malampaya, Offshore Palawan, Philippines. Marine and Petroleum Geology, 21 (1): 1-21.

http://dx.doi.org/10.1016/j.marpetgeo.2003.11.012

Geel, T. 2000, Recognition of Stratigraphic sequence in carbonate platform and slope deposits: empirical models based on microfacies analyses of palaeogene deposits in southeastern Spain: Palaeogeography, Palaeoclimatology, Palaeoecology, 155: 211-238.

http://dx.doi.org/10.1016/S0031-0182(99)00117-0

Gradstein, F.M., Ogg, J. \& Smith, A.G. 2004, A Geological Time Scale 2004. Cambridge University Press, Cambridge, 589 p. http://dx.doi.org/10.4095/215638

Hallock, P., Glenn, E.C. 1986, Larger foraminifera: a tool for paleoenvironmental analysis of Cenozoic carbonate depositional facies. Palaios, 1: 55-64. http://dx.doi.org/10.2307/3514459

Haq, B.U., Hardenbol, J. \& Vail, P.R. 1987, Chronology of fluctuating sea levels since the Triassic. Science, 235: 1156-1167. http://dx.doi.org/10.1126/science.235.4793.1156

Hessami, K., Koyi, H., Talbot, C.J., Tabasi, H. \& Shabanian, E. 2001, Progressive unconformities within an evolving foreland fold-thrust belt, Zagros Mountains. Journal of the Geological Society, 158: 969-981.

http://dx.doi.org/10.1144/0016-764901-007

Heydari, E., Hassanzadeh, J., Wade, W.J. \& Ghazi, A.M. 2003, Permian-Triassic boundary interval in the Abadeh section of Iran with implications for mass extiontion. Part 1. Sedimentology: Palaeogeography, Palaeoclimatology, Palaeoecology, 193: 405-423.

http://dx.doi.org/10.1016/S0031-0182(03)00258-X

James, G.S., Wynd, J.G. 1965, Stratigraphic nomenclature of Iranian Oil Consortium Agreement area. American Association of Petroleum Geologists Bulletin, 49: 2182-2245.

Lacombe, O., Grasemann, B. \& Simpson, G. 2011, Introduction: geodynamic evolution of the Zagros. Geodynamic Magazin, 148 (5-6): 689-691. http://dx.doi.org/10.1017/S0016756811000550

Laursen, G.V., Monibi, S., Allan, T.L., Pickard, N.A., Hosseiney, A., Vincent, B., Hamon, Y., Van-Buchem, F.S.P., Moallemi, A. \& Druillion, G. 2009, The Asmari Formation Revisited: Changed Stratigraphic Allocation and New Biozonation, First International Petroleum Conference \& Exhibition, European Association of Geoscientists and Engineers.

Lees, G.M. 1933, The reservoir rocks of Persian oil fields. American Association Petroleum Geology Bulletin, 17: 224-240.

Mossadegh, Z.K., Haig, D.W., Allan, T., Adabi, M.H. \& Sadeghi, A. 2009, Salinity changes during Late Oligocene to Early Miocene Asmari Formation deposition, Zagros Mountains, Iran. Palaeogeography, Palaeoclimatology, Palaeoecology, 272: 17-36. http://dx.doi.org/10.1016/j.palaeo.2008.10.021
Nebelsick, J.H., Bassi, D. 2000, Diversity, growthforms and taphonomy: key factors controlling the fabric of coralline algal dominated shelf carbonates. In Carbonate platform systems. Components and interactions (Insalaco, E., Skelton, P. \& Palmer, T., Eds.), Geological Society, 178: 89-107.

Nebelsick, J.H., Stingl, T.V. \& Rasser, M. 2001, Autochthonous facies and allochthonous debris flows compared: Early Oligocene carbonate facies patterns of the lower Inn valley (Tyrol, Austria). Facies. 44: 31-46. http://dx.doi.org/10.1007/BF02668165

Pirouz, M., Simpson, G., Bahroudi, A. \& Azhdari, A. 2011, Neogene sediments and modern depositional environments of the Zagros foreland basin system. Geological Magazine, 148: 838-853. http://dx.doi.org/10.1017/S0016756811000392

Pomar, L. 2001, Types of carbonate platforms: a genetic approach. Basin Research, 13: 313-334. http://dx.doi.org/10.1046/j.0950-091x.2001.00152.x

Posamentier, H.W., Vail, P.R. 1988, Eustatic controls on clastic deposition II-sequence and systems tract models. In Sea-level changes. An integrated approach (Wilgus, C.K., Hastings, B.S., Kendall, C.G.S, Posamentier, H.W., Ross, C.A. \& Van Wagoner, J.C., Eds.), Society of Economic Paleontologists and Mineralogists Special Publications, 42: 125-154.

Rasser, M.W., Scheibner, C. \& Mutti, M. 2005, A paleoenvironmental standard section for Early Ilerdian tropical carbonate factories (Corbieres, France; Pyrenees, Spain). Facies, 51: 217-232. http://dx.doi.org/10.1007/s10347-005-0070-9

Richardson, R.K. 1924, The geology and oil measures of southwest Persia. Journal of Petroleum Technology, 1: 256-283.

Romero, J., Caus, E., Rossel, J. 2002, A model for the palaeoenvironmental distribution of larger foraminifera based on Late Middle Eocene deposits on the margin of the south Pyrenean basin. Palaeogeography, Palaeoclimatology, Palaeoecology, 179: 43-56. http://dx.doi.org/10.1016/S0031-0182(01)00406-0

Sarg, J.F. 1988, Carbonate sequence stratigraphy. SEPM Special Publications, 42: 155-188.

Seyrafian, A. 2000, Microfacies and depositional environments of the Asmari Formation, at Dehdez area (a correlation across central Zagros Basin). Carbonates and Evaporites, 15: 121-129. http://dx.doi.org/10.1007/BF03175819

Schuster, F., Wielandt, U. 1999, Oligocene and Early Miocene coral faunas from Iran. palaeoecology and palaeobiogeography. International Journal of Earth Sciences, 88: 571-581. http://dx.doi.org/10.1007/s005310050285

Thomas, A.N. 1948, The Asmari limestone of southwest Iran. AngloIranian Oil Company Report, 706 p (unpublished).

Thomas, A.N. 1950, The Asmari Limestone of south-west Iran. In The Geology of Petroleum (Hobson, G.D., Ed.), IGC Publication, p. 35-44.

Van Boeckh, H.D.E., Lees, G.M. \& Richardson, F.D.S. 1929, Contribution to the stratigraphy and tectonics of Iranian ranges. In The structure of Asia (Gregory, J.W., Ed.), 88-177. 
Van Buchem, F.S.P., Allan, T.L., Laursen, G.V., Lotfpour, M., Moallemi, A., Monibi, S., Motiei, H., Pickard, N.A.H., Tahmasbi, A.R., Vedrenne, V. \& Vincent, B. 2010, Regional stratigraphic architecture and reservoir types of the Oligo-Miocene deposits in the Dezful Embayment (Asmari and Pabdeh Formations), SW Iran. Geological Society, 329: 219-263. http://dx.doi.org/10.1144/SP329.10 Vaziri-Moghaddam, H., Kimiagari, M. \& Taheri, A. 2006, Depositional environment and sequence stratigraphy of the Oligocene-Miocene Asmari Formation in SW Iran, Lali Area. Facies, 52: 41-51. http://dx.doi.org/10.1007/s10347-005-0018-0
Wanas, H.A. 2008, Cenomanian rocks in the Sinai Peninsula, Northeast Egypt: Facies analysis and sequence stratigraphy. Journal of African Earth Sciences, 52: 125-138. http://dx.doi.org/10.1016/j.jafrearsci.2008.06.004

Wilson, J.L. 1975, Carbonate facies in geologic history. Springer-Verlag, Berlin, 471p.

http://dx.doi.org/10.1007/978-1-4612-6383-8

Wynd, J.G. 1965, Biofacies of the Iranian consortium-agreement area. Unpublished Report 1082, Tehran, Iranian Oil Operating Companies, Geological and Exploration Division. 